\title{
Contraceptive Use Dropout-adjusted Unmet Need for Family
}

\section{Planning [version 1; peer review: 1 approved with}

\section{reservations, 1 not approved]}

\author{
Budi Utomo1, Hariyanti Hariyanti (iD2, Sabarinah Prasetyo1, Robert Magnani33, \\ Sukma Rahayu(ii) 3 \\ ${ }^{1}$ Biostatistics and Population, Faculty of Public Health Universitas Indonesia, Depok, 16424, Indonesia \\ 2Indonesia Health Polytechnic Ministry of Health Jakarta 1, South Jakarta, 12450, Indonesia \\ ${ }^{3}$ Knowledge Hub for Reproductive Health, Faculty of Public Health Universitas Indonesia, Depok, 16424, Indonesia
}

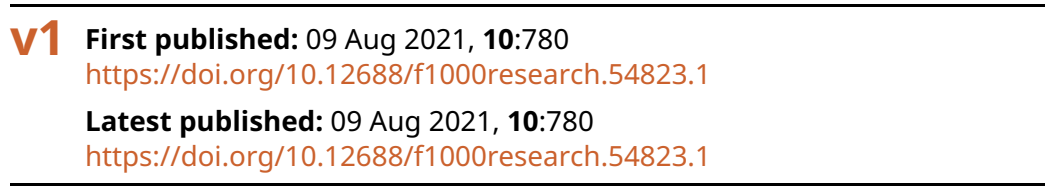

\section{Abstract}

Background: In the last two decades, unmet need for family planning in Indonesia remains stagnant, and contraceptive discontinuation has increased. These two indicators describe the risk of unwanted pregnancy in a population. Therefore, this study aims to develop an accurate calculation of the unmet need for family planning in Indonesia.

Method: The study uses 2017 IDHS data to compare unmet need at survey-time and five years preceding the survey, measured by contraceptive calendar data that measured history of contraceptive use within five years preceding the survey. Unmet need at five years preceding the survey is measured by calculating the proportion of months not using contraceptive to the duration of months exposed to pregnancy in a period of 69 months. The study population is married women in Indonesia, with a sample size of 35,681.

Results: Unmet need with contraceptive calendar calculation is higher than unmet need at survey-time. A difference of $3 \%$ concerns an additional of nearly 1.6 million unwanted pregnancies. This study proves that the high number of contraceptive discontinuations is directly proportional to higher unmet need with contraceptive calendar calculation.

Conclusion: In Indonesia, with a relatively high contraceptive discontinuation rate, the calculation of unmet need using the calendar method is more precise than at survey-time method. The study results suggest the use of unmet need calendar for countries with high contraceptive discontinuation rate and provision of primary health care that is responsive to a potential unwanted pregnancy.

\section{Open Peer Review}

\begin{tabular}{lcc} 
Approval Status & X ? \\
& 1 & 2 \\
\hline version 1 & $\times$ & $?$ \\
09 Aug 2021 & view & view
\end{tabular}

1. Ilene S. Speizer ${ }^{D}$, University of North

Carolina at Chapel Hill, Chapel Hill, USA

2. Siswanto Agus Wilopo (iD), Universitas

Gadjah Mada, Yogyakarta, Indonesia

Any reports and responses or comments on the article can be found at the end of the article. 


\section{Keywords}

Contraceptive calendar data, Family planning, Contraception,

Contraceptive discontinuation, Unmet need.

\section{Corresponding author: Sukma Rahayu (sukmarahayu47@gmail.com)}

Author roles: Utomo B: Conceptualization, Methodology, Supervision, Validation, Writing - Review \& Editing; Hariyanti H: Conceptualization, Formal Analysis, Funding Acquisition, Methodology, Visualization, Writing - Original Draft Preparation; Prasetyo S:

Supervision, Writing - Review \& Editing; Magnani R: Supervision, Writing - Review \& Editing; Rahayu S: Formal Analysis, Writing -

Original Draft Preparation, Writing - Review \& Editing

Competing interests: No competing interests were disclosed.

Grant information: This research was funded by a Ministry of Health of the Republic of Indonesia in study assignment scholarship with grant number HK.02.02/H.V/SK/169/2016 to Mrs. Hariyanti and received special recognition scholarship from UNFPA Indonesia for publication fees under the implementing agreement between UNFPA and Faculty of Public Health Universitas Indonesia for 2021-2025 UNFPA country program.

The funders had no role in study design, data collection and analysis, decision to publish, or preparation of the manuscript.

Copyright: (c) 2021 Utomo B et al. This is an open access article distributed under the terms of the Creative Commons Attribution License , which permits unrestricted use, distribution, and reproduction in any medium, provided the original work is properly cited. The author(s) is/are employees of the US Government and therefore domestic copyright protection in USA does not apply to this work. The work may be protected under the copyright laws of other jurisdictions when used in those jurisdictions.

How to cite this article: Utomo B, Hariyanti H, Prasetyo $S$ et al. Contraceptive Use Dropout-adjusted Unmet Need for Family Planning [version 1; peer review: 1 approved with reservations, 1 not approved] F1000Research 2021, 10:780 https://doi.org/10.12688/f1000research.54823.1

First published: 09 Aug 2021, 10:780 https://doi.org/10.12688/f1000research.54823.1 


\section{Introduction}

Unmet need for family planning refers to those who are fecund and sexually active, but are not using any method of contraception, and report a desire to delay or limit childbearing. Women with unmet need are exposed to risk of unwanted pregnancy, unsafe abortions, and maternal death. ${ }^{1}$ Globally, there are 80 million unwanted pregnancies and 40 million abortions every year due to unmet need..$^{2}$ In developing countries, around 222 million women experience unmet needs, and in Indonesia, around 1.000 births are unwanted or wanted later. ${ }^{3,4}$

Referring to the history of family planning in Indonesia, in the 1970s, the family planning program was a national program aimed at population control. The indicators used were Contraceptive Prevalence Rate (CPR) and Contraceptive Years Protection (CYP), which were used to assess the decline in fertility. In 1994, the International Conference for Population \& Development (ICPD) was held to introduce the concept of reproductive health and in 2012, the 2020 Family Planning was held to emphasized rights-based reproductive health. ${ }^{5}$ The perspective of the family planning program then has been oriented towards reproductive health and measured by the unmet need indicator to assess the risk of unwanted pregnancy which has an impact on maternal mortality. ${ }^{6}$ Furthermore, to achieve universal access to sexual and reproductive health and rights as a part of universal health coverage, the World Health Organization (WHO) and the United Nations Fund for Population Activities commiting to strive for zero unmet need for family planning information and services, and universal availability of quality, accessible, affordable and safe modern contraceptives.

The achievement of family planning programs in Indonesia based on the 1991 to 2017 DHS shows that the unmet needs are in stagnant trend in last two decades while contraceptive discontinuation has increased. Unmet needs and contraceptive discontinuation capture the same phenomenon: women who do not use contraception are at risk of unwanted pregnancies. However, the data for these two indicators show contradictions. ${ }^{8-13}$

The progress of family planning program achievement becomes the basis for reviewing unmet need measurements in Indonesia. The standard of unmet need measurement is calculated based on the status of contraceptive use at survey time. This study develops an unmet need measurement based instead on contraceptive use within the five years preceding the survey which is termed the unmet need with calendar data. ${ }^{14}$ It takes into account the duration of contraceptive use, pregnancy and marriage, so conceptually the method would be more precise in estimating the risk of unwanted pregnancy in Indonesia.

\section{Methods}

The study using a cross-sectional research design by analyzing the 2017 the publicly available database of Indonesia Demographic Health Survey that conducted by National Population and Family Planning Board, Statistics Indonesia, Ministry of Health and The DHS Program or ICF. The IDHS 2017 data are considered adequate in quality for statistical analysis as the survey report has been officially published and the survey data have been used in published studies. The studied population were currently married women with total of 35,681 women.

This study used reproductive and contraceptive calendar data which records several dimension on the history of reproductive and contraceptive events, such as: 1) Birth history; 2) Pregnancy; 3) Birth termination; 4) Current contracpetive use; 5) Episodes of contraceptive use during calendar period. The study focused on duration not protected by contraceptive use, described as measured in women of reproductive age who did not use contraception in the five years preceding the survey, which in IDHS 2017 was 69 months. These measurements were made after determining the study population, which then retrospectively reviewed the history of contraceptive use at 69 months prior to the survey. The data was analyzed by SPSS version 23.0 statistical packages (IBM SPSS Statistics, RRID:SCR_019096).

The detailed calculations of duration not protected by contraceptives are shown in Figure 1.

Figure 1 explains that survey-time unmet need is measured based on contraceptive use status at the time of survey, while unmet need with calendar data is measured based on contraceptive use within the 69 months preceding the survey. The figure shows that unmet need at survey-time is limited by the marital status, which is the inclusion criteria in this study. The duration of not protected by contraceptive was carried out indirectly from calculating the duration of marriage, duration of contraceptive use, and pregnancy duration. This is to avoid the period before marriage within five years preceding the survey taken into account in the measurement.

Duration of contraceptive use is calculated by adding up the person months of contraceptive use, either modern or traditional, over a period of 69 months for each individual. Pregnancy events, live births, stillbirths, abortions and duration of marriage were calculated as the duration of pregnancy in the same way as duration of contraceptive use. The formula to calculate the duration of not protected by contraceptive use is obtained as follows:

Duration of not protected $=$ duration of marriage $-($ duration of using contraceptive + duration of pregnancy $)$ 


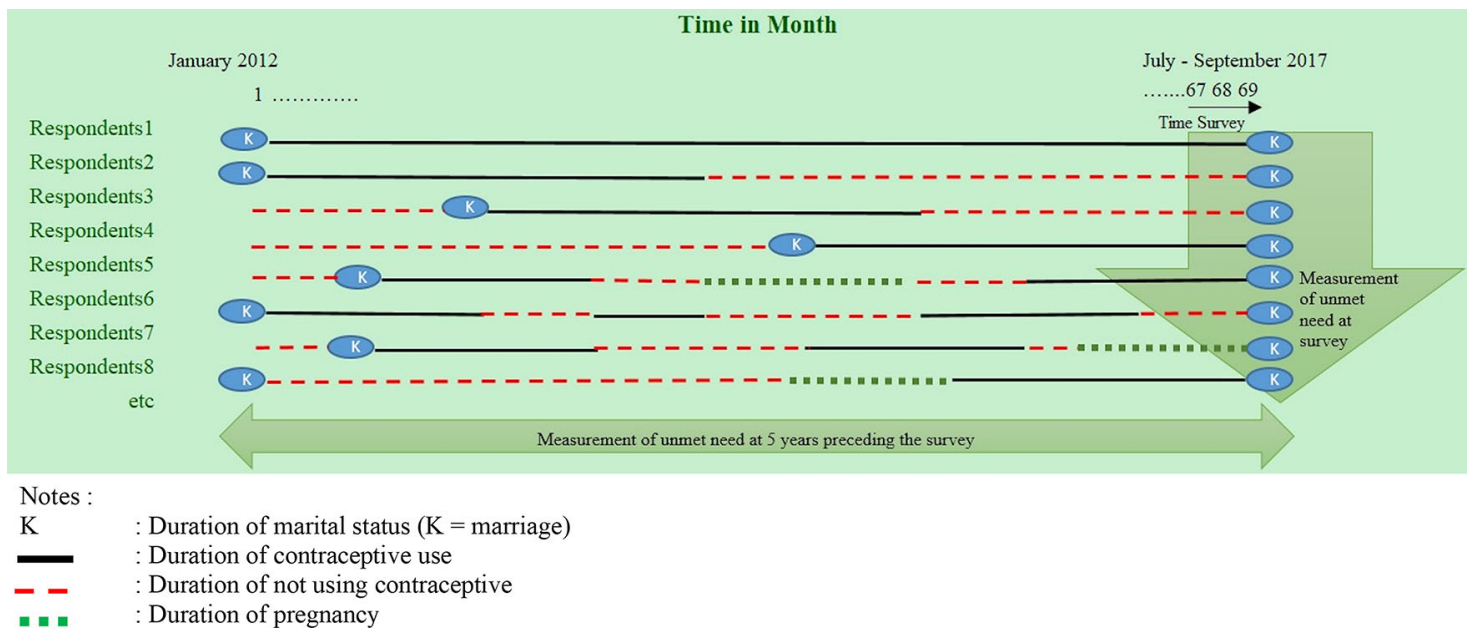

Figure 1. Illustrations of unmet need measurements at survey time and with calendar data.

Based on the formula, the calculation of unmet need with contraceptive calendar data is as shown below:

$$
\text { Unmet need with calendar data }=\frac{\sum \text { Duration of not using contraceptive }}{\sum \text { Duration of marriage }} \times 100
$$

Differences between calculation of unmet need at survey time and with contraceptive calendar data are explained on Table 1.

\section{Result}

Table 2 shows that the unmet need at survey time among married women was $10.5 \%$, lower than unmet need with calendar data (13.1\%). This difference of about 3\% concerns almost 1.6 million additional women at risk of unwanted pregnancy. The magnitue of the difference depends on the contraceptive prevalence rate, method mix, and discontinuation rate in the coutry at the time of the survey.

Table 1. Unmet need measurements.

\begin{tabular}{|l|l|l|}
\hline Unmet need at survey time & Unmet need with calendar data \\
\hline Numerator & $\begin{array}{l}\text { Number of women who want to delay or limit } \\
\text { childbearing but not using contraceptive }\end{array}$ & $\begin{array}{l}\text { Number of months not protected by } \\
\text { contraceptive }\end{array}$ \\
\hline Denominator & Number of married women & Number of months married \\
\hline
\end{tabular}

Table 2. Pregnancy and contraceptive use among married women, IDHS 2017.

\begin{tabular}{|l|l|l|l|l|l|}
\hline Unmet need at survey time & \multicolumn{3}{|c|}{ Unmet need with calendar data } & \\
\hline Contraceptive use status & $\mathbf{n}$ & $\%$ & Duration of contraceptive use & $\begin{array}{l}\text { Person- } \\
\text { months }\end{array}$ & $\%$ \\
\hline Using contraceptive (met need) & 22.696 & 63,6 & $\begin{array}{l}\text { Duration protected by } \\
\text { contraceptive }\end{array}$ & 1.381 .311 & 62,9 \\
\hline $\begin{array}{l}\text { Not using contraceptive but do } \\
\text { not want to become pregnant } \\
\text { (unmet need) }\end{array}$ & 3.740 & 10,5 & $\begin{array}{l}\text { Duration not protected by } \\
\text { contraceptive, but do not want } \\
\text { children }\end{array}$ & 287.473 & 13,1 \\
\hline $\begin{array}{l}\text { Not using contraceptive but } \\
\text { wanted children within 2years (no } \\
\text { need) }\end{array}$ & 9245 & 25,9 & $\begin{array}{l}\text { Duration not protected by } \\
\text { contraceptive, but wanted } \\
\text { children within 2 years }\end{array}$ & 354619 & 16,2 \\
\hline $\begin{array}{l}\text { Total } \\
\text { Duration of sexually active (Total) }\end{array}$ & 2.195 .825 & 100 \\
\hline
\end{tabular}




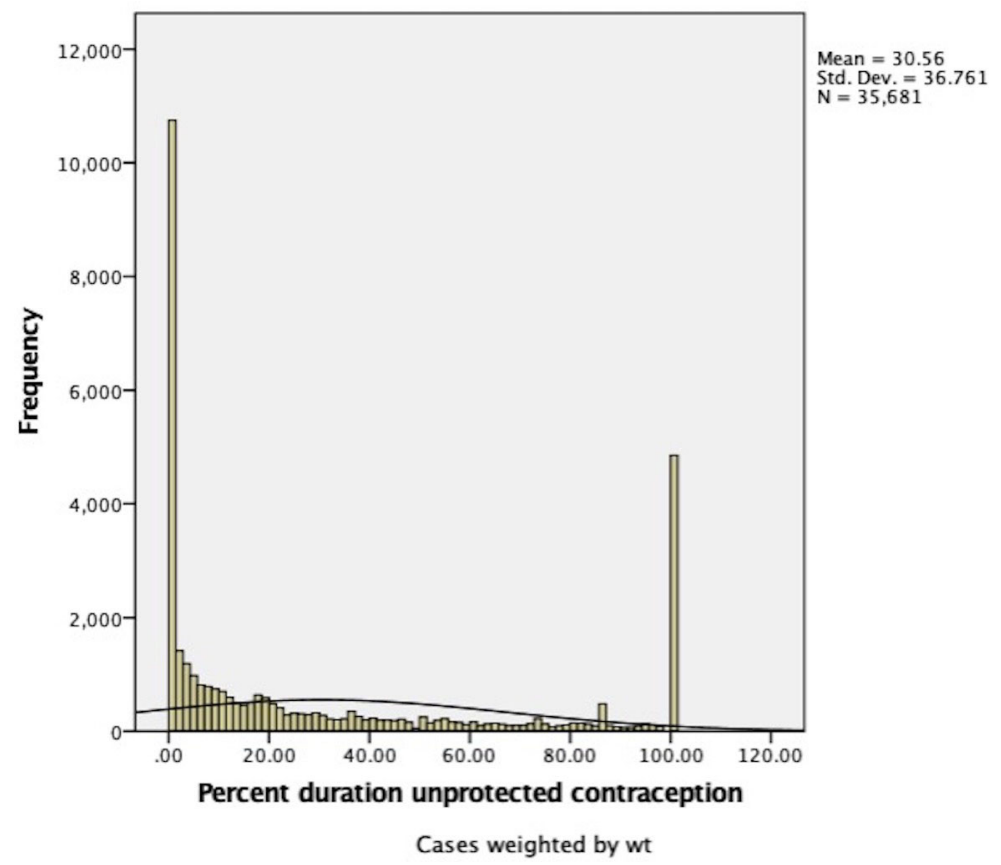

Figure 2. Percent duration of not protected by contraceptive on married women, IDHS 2017.

It should be noted that measurements of unmet need in the field are dynamic. Reproductive intentions as part of the calculation of unmet need are known to be unstable over the long-term, even in the span of few weeks. Fertility intentions were also unstable among a reference group of family planning users. ${ }^{15}$ This study did not assess the status of contraceptive use before pregnancy and treated the duration of pregnancy as not to have unmet need. Treating women who are pregnant or postpartum amenorrheic as not in need of family planning decreases the level of unmet need. Intendedness of pregnancies are likely to be biased as pregnant women don't generally view themselves as having unmet need, regardless whether their pregnancy was accidental.

Another finding (Figure 2) shows that average duration of not protected by contraceptive use is $30.6 \%$ meaning that unwanted pregnancy might occur in one-third of the marriage period. Only one-third of respondents used contraception in the full observation period (69 months), and $13.6 \%$ of respondents have never used contraception at all.

\section{Discussion}

Unmet need for family planning in the IDHS report was measured using point prevalence whereas in this study, it was measured using period prevalence. This aims to focus on the duration of not protected by contraceptives and at risk of unwanted pregnancy. Previous studies suggest that the measurement for standard unmet need does not reflect the percentage of women at risk of unintended pregnancy who are not using contraception, and a complementary measure of unmet need will be helpful to identify the target population in need of contraceptive services. Another research modified unmet need measurement by removing the categories of women included in standard unmet need calculation by limiting the population study to age 44 years, removing permanent (female and male sterilization) family planning users, infecund women, currently pregnant women who wanted the pregnancy, and non-pregnant women who want a child within two years. ${ }^{16,17}$

This study show that the unmet need estimated at survey-time is lower than unmet need with calendar data which illustrates the risk of unwanted pregnancy more accurately in a population, but calendar data does have the potential for under-reporting and recall bias. On the other hand, the under-reported potential might show that the unmet need for family planning in the population is much higher than the results of this study. ${ }^{14}$

The measurement of unmet need with calendar data is more appropriate than standard methods in countries where contraceptive discontinuation rates are still high. This is indicated by the higher value of unmet need proportion with calendar data compared to the standard method. The study prove that contraceptive discontinuation rates are directly proportional to unmet needs using the calendar method. The results found that nearly 1.6 million additional married women in Indonesia are at risk of experiencing unwanted pregnancy. 
The calculation of the duration of not protected by contraceptives was measured in women who did not use contraception in a period of 69 months based on the status of unmet need at the time of the survey, while the status of no need at the time of the survey was used to calculate the duration of not using contraception for women who wanted to become pregnant within 69 months. The duration of no need is not included as the numerator for calculating the unmet need with the calendar method. Calculation of duration with no need status or wanting to get pregnant in the study was calculated as $35 \%$ (duration not protected by contraception because you want to get pregnant divided by the total duration not protected by contraception). This result is not much different from the 2017 IDHS report which explains the contraceptive discontinuation with 'wanted to get pregnant' reason is $30 \%$, while $70 \%$ do not want to get pregnant. Thus, the assumption of contraceptive use status during the survey, which is then used as the basis for calculating the duration of unprotected contraception, is acceptable.

Previous research stated that health reproductive age couples who had frequent unprotected sexual intercourse have a $20 \%$ chance of getting pregnant in one cycle. ${ }^{18}$ The pregnancy rates increase over time, namely $57 \%$ of women will become pregnant in the first three months and then rates increase $15 \%$ in the next three months. Another study showed that $30 \%$ of women became pregnant in first month, $50 \%$ pregnancies occuring within two months, and $80 \%$ of pregnancies occuring within six months, and for couples who do not use contraceptive method within 12 months, $85 \%$ are at risk of pregnancy. ${ }^{19,20}$ This study showed that $35 \%$ of women experienced discontinuation and were at risk of unwanted pregnancy. A previous study described cumulative pregnancy rate for one year after contraceptive discontinuation as $72-85 \%$ for IUDs, $75-81 \%$ for pills, $72-76 \%$ for implants, and $65-67 \%$ for injectables. $^{21}$

Based on the above findings, it is necessary for the government of Indonesia to equip primary health care services in a way which is responsive to unwanted pregnancies. The 2019 Health Facilitiy Research show that Indonesia only has $30.4 \%$ Puskesmas with Basic Obstetric and Neonatal Emergency Service (PONED) with Banten (59.7\%) for the highest and West Papua (9.6\%) for the lowest. ${ }^{22}$ Policy adjustments are needed in order to anticipate the low demand satisfied in Indonesia.

\section{Conclusion}

Unmet need of family planning is a crucial measure to assess the achievement of family planning programmes. The results show that for Indonesia context with a relatively high contraceptive discontinuation rate, the measurement of unmet need for family planning need adjusment, where using contraceptive calendar data for five years preceding the survey is more appropriate than at survey time. The results also showed that the average percentage of duration not using contraception was one-third of marriage period and at risk of unwanted pregnancies. Policy makers such as National Family Planning Coordination Board (BKKBN) and Ministry of Health need to adjust the calculation of demand satisfied considering the high contraceptive discontinuation in Indonesia. They also need to equip primary health care services with PONED in order to be responsive for unwanted pregnancy.

\section{Declarations}

Ethical approval

This article is part of a dissertation result that has received approval from the Ethics Comission for Research and Community Health Service, Faculty of Public Health, Universitas Indonesia, Letter Number 670/UN2.F10/PPM. $00.02 / 2019$, on November $13^{\text {th }}, 2019$.

\section{Data and material availability}

The underlying data for this study is owned y the DHS Program (https://dhsprogram.com/methodology/survey/surveydisplay-522.cfm). The electronic data is available from the DHS Program under its terms of use (https://dhsprogram.com/ Data/terms-of-use.cfm) . Before downloading the data, users must register as a DHS user for reasons laid out on the DHS Program website (https://www.dhsprogram.com/data/Registration-Rationale.cfm) and dataset access is only granted for legitimate research purposes.

\section{Author contribution}

Author $1(\mathrm{BU})$ - Conceived of the presented idea, developed the theory and supervised the findings of this work.

Author $2(\mathrm{H})$ - Carried out the analysis and wrote the manuscript.

Author 3 (SBP) - Verified the analytical methods and supervised the findings of this study.

Author $4(\mathrm{RM})$ - Verified the analytical methods and supervised the findings of this study.

Author 5 (SR) - Together with Author 2, wrote the manuscript with input from all authors. 


\section{Acknowledgment}

I would like to thank the Poltekkes Ministry of Health Jakarta I for providing assistance and support in completing this research and FPH UI as a place to study and gain knowledge so that this research was completed properly on time.

\section{References}

1. Bradley SEK, Croft TN, Fishel JD: Revising Unmet Need for Family Planning: DHS Analytical Studies No. 25. 2012 25(January): 63.

2. Sedgh $G$, Singh $S$, Hussaina R: Intended and Unintended Pregnancies Worldwide in $\mathbf{2 0 1 2}$ and Recent Trends. Stud Fam Plann. 2014; 45(3): 301-14.

PubMed Abstract | Publisher Full Text | Free Full Text

3. UNFPA: Choices not Chance- UNFPA Family Planning Strategy 2012-2020. Unfpa. 2012.

4. BKKBN, BPS, Kemenkes, ICF: Survei Demografi dan Kesehatan Indonesia 2017. 2018.

5. Wilopo SA: Hasil Konferensi Kependudukan di Kairo: Implikasinya pada Program Kesehatan Reproduski di Indonesia. Populasi. 1994; 5(2): 1-29. Publisher Full Text

6. BKKBN, BAPPENAS, Kemenkes, UNFPA, CANADA: Program Keluarga Berencana Berbasis Hak untuk Percepatan Akses terhadap Pelayanan Keluarga Berencana dan Kesehatan Reproduksi yang Terintegrasi dalam Mencapai Tujuan Pembangunan Indonesia. 2012.

7. BKKBN: Tantangan Keluarga Berencana Dan Kesehatan Reproduksi Menjadi Pembahasan Utama Pada Konferensi Internasional. SIARAN PERS No. RILIS/103/B4/BKKBN/IX/2019. 2019

8. Central Bureau of Statistic, National Family Planning Coordinating Board M of H: Indonesia 1991 DHS Summary Report (English).pdf. 1991.

9. BPS CB of S. 1994 SR.pdf.1994.

10. BPS CB of S. DHS 1997.pdf.1997.

11. Badan Pusat Statistik BK dan KB: Laporan Survei Demografi dan Kesehatan Indonesia 2007. 2008;
12. Badan Pusat Statistik, Badan Koordinasi Keluarga Berencanan Nasional, Departemen Kesehatan, Macro International: Surve Demografi dan Kesehatan Indonesia 2012. Sdki. 2013: 16.

13. BKKBN, Badan Pusat Statistik, Kementerian Kesehatan, IFC International: Survei Demografi dan Kesehatan Indonesia 2017. Sdki. 2017: 16.

14. USAID: DHS Contraceptive Calendar Tutorial. 2018. 4-48 p.

15. Staveteig $\mathrm{S}$ : Understanding unmet need in Ghana: Results from a follow-up study to the 2014 Ghana Demographic and Health Survey. DHS Qual Res Stud No 20 [Internet]. 2016; (January). Reference Source

16. Bradley SE, Casterline JB: Understanding Unmet Need: History Theory, and Measurement. Stud Fam Plann. 2014; 45(2): 123-50. PubMed Abstract | Publisher Full Text | Free Full Text

17. Moreau $C$, Shankar M, Helleringer $S$, et al.: Measuring unmet need for contraception as a point prevalence. BMJ Glob Heal. 2019; 4(4): $1-12$. PubMed Abstract | Publisher Full Text | Free Full Text

18. Makar RS, Toth TL: The Evaluation of infertility. Hum Reprod Update. 2002; 1(6): 586-606 PubMed Abstract | Publisher Full Text

19. Joffe M: Time to pregnancy: A measure of reproductive function in either sex. Occup Environ Med. 1997; 54(5): 289-95. PubMed Abstract | Publisher Full Text | Free Full Text

20. Hatcher RA, Trussell J, Nelson AL, et al.: Contraceptive Technology. reproducti. ob/gyns, reproductive medicine MDs and primary care physicians, editor. 2007; 874 p.

21. Gayatri M: Menepis Mitos Kemandulan Akibat Kontrasepsi: Analisis Kesintasan Data Kalender Kontrasepsi Dan Kehamilan SDKI 2007, 2012 Dan 2017. Universitas Indonesia; 2019.

22. Kemenkes RI: Riset Fasilitas Kesehatan Rifaskes 2019. 2020. 


\section{Open Peer Review}

\section{Current Peer Review Status: $\mathrm{X}$ ?}

\section{Version 1}

Reviewer Report 17 November 2021

https://doi.org/10.5256/f1000research.58343.r98878

(C) 2021 Wilopo S. This is an open access peer review report distributed under the terms of the Creative Commons Attribution License, which permits unrestricted use, distribution, and reproduction in any medium, provided the original work is properly cited.

\section{Siswanto Agus Wilopo}

Center for Reproductive Health, Universitas Gadjah Mada, Yogyakarta, Indonesia

The author stated that: "the achievement of family planning programs in Indonesia based on the 1991 to 2017 DHS shows that the unmet needs are in stagnant trend in last two decades while contraceptive discontinuation has increased." This statement is the reason to develop a new method of unmeet-need calculation. The existing unmet need is based on the prevalence (\%) calculation while their method is based on a rate of person month calculation (rate from cohort observation). Certainly, we can have difference results due to these calculations. The unmet need calculation includes traditional method which result of low unmet need for Indonesia. Will the result show a similar unmet need when calculation is limited to modern of contraceptives method? Moreover, their model did not explain impact of the birth termination due to abortion. This information will influence the duration of not using contraception which ultimately to an unmet need. Authors need to explain why two methods are not giving same results.

Is the rationale for developing the new method (or application) clearly explained? Partly

Is the description of the method technically sound?

Partly

Are sufficient details provided to allow replication of the method development and its use by others?

Yes

If any results are presented, are all the source data underlying the results available to ensure full reproducibility?

Yes

Are the conclusions about the method and its performance adequately supported by the findings presented in the article? 
Partly

Competing Interests: No competing interests were disclosed.

Reviewer Expertise: Reproductive health

I confirm that I have read this submission and believe that I have an appropriate level of expertise to confirm that it is of an acceptable scientific standard, however I have significant reservations, as outlined above.

Reviewer Report 17 November 2021

https://doi.org/10.5256/f1000research.58343.r98880

(c) 2021 Speizer I. This is an open access peer review report distributed under the terms of the Creative Commons Attribution License, which permits unrestricted use, distribution, and reproduction in any medium, provided the original work is properly cited.

\section{Ilene S. Speizer}

Department of Maternal and Child Health, Gillings School of Global Public Health, Carolina Population Center, University of North Carolina at Chapel Hill, Chapel Hill, NC, USA

This study presents a novel measure of unmet need using 5-year calendar data. The authors demonstrate that the standard survey-time unmet need underestimates overall unmet need in Indonesia. While I find this to be an intriguing study, I did have a number of major and minor comments.

\section{Major comments:}

1. The authors state that unmet need between 1991 and 2017 is stagnant while discontinuation is on the rise. The values for unmet need and discontinuation over time are not presented nor is contraceptive use and method mix provided. This left me wondering if discontinuation is on the rise because of a change in method mix (i.e., transition from IUD to implants where side effects may be more common and causing discontinuation). Also, given that in 2017 unmet need is $10.5 \%$ (shown in Table 2), it is possible that it will not decline much more given that it is a research (and not individual) defined measure and women may choose not to use.

2. From my understanding of the approach to calculate the novel measure, any period when a woman is in union and not pregnant and not using has an unmet need. The authors argue that fertility intentions are fluid and thus not reliable and thus not part of the calculation; however, intentions are used for the "duration with no need measure" it seems. This seems inconsistent. Also, what time point is used for the fertility intentions in that measure - is it at the time of the current survey and then applied retrospectively? Further, in Table 2 you indicate that women do not want children (or want to delay) in the unmet need with calendar data measure presented on the right - so where does the information on fertility desires come from (and what time period)? 
3. The rationale for this measure is not completely clear. Unmet need in its current form is already hypothetical and meant to be used at the aggregate and not individual level. As the authors rightly point out, there are flaws with unmet need including that it treats pregnant women with an unintended pregnancy as having an unmet need and does not reflect women's desire or intentions to use a method. But their hypothetical measure has the same problems, and others, so why develop a measure that requires a lot of data to capture (including calendar data that is not always obtained and has known flaws) and does not fix the identified problems.

\section{Minor comments:}

1. You say that your sample is currently married women (and you give a specific number of women). My guess is that this is the number of women at the time of the survey but since the analysis is by episodes and some women may have been married earlier (and not married at the time of the survey), I wasn't sure what the number of women was representing.

2. There are a lot of statements about "unwanted pregnancy" prevention and that the new measure demonstrates more women at risk of unintended pregnancy. However, this assumes that all women who are non-users want to delay or avoid childbearing and that they intend to use contraception. Many women may choose not to use contraception and then might not declare a subsequent pregnancy as unintended.

3. Details are provided on obstetric and neonatal care services but not on access to family planning services and provision of a full range of methods. Perhaps this oversight is because $100 \%$ of facilities offer family planning which would be great. But it is not clear why recommendations are made about obstetric and neonatal care based on this analysis.

4. CYP is couple years of protection (and not contraceptive years of protection).

5. The last sentence of the first paragraph of the results "The magnitude of the differences..." This is a key point, but no information is given on these key issues (see major point above).

6. The first paragraph of the discussion says that the new method is aiming to determine the duration of not protected by contraception and at risk of unwanted pregnancy, but this assumes that fertility desires are measured. It is not clear where fertility desires are coming from here.

7. The paragraph on the calculation of the duration not protected in the discussion lost me. It says it is based on the status of unmet need at the time of the survey and also mentions focusing on women who wanted to become pregnant within 69 months. I read the paragraph multiple times and am still not sure what it is demonstrating and how fertility intentions are being used (from the time of the survey and applied retrospectively?).

8. The grammar throughout this paper needs to be checked.

Is the rationale for developing the new method (or application) clearly explained? Partly

Is the description of the method technically sound? 


\section{Partly}

Are sufficient details provided to allow replication of the method development and its use by others?

Yes

If any results are presented, are all the source data underlying the results available to ensure full reproducibility?

Yes

Are the conclusions about the method and its performance adequately supported by the findings presented in the article?

Partly

Competing Interests: No competing interests were disclosed.

Reviewer Expertise: Demography, fertility, family planning, unintended pregnancy research.

I confirm that I have read this submission and believe that I have an appropriate level of expertise to state that I do not consider it to be of an acceptable scientific standard, for reasons outlined above.

The benefits of publishing with F1000Research:

- Your article is published within days, with no editorial bias

- You can publish traditional articles, null/negative results, case reports, data notes and more

- The peer review process is transparent and collaborative

- Your article is indexed in PubMed after passing peer review

- Dedicated customer support at every stage

For pre-submission enquiries, contact research@f1000.com 